\title{
Стан психофізіологічних функцій і динамічна м'язова витривалість у спортсменок в ігрових видах спорту
}

\author{
УДК 796.012.1+159.91:796.3 \\ С. Федорчук, О. Шльонська, О. Борисова, І. Когут, \\ В. Маринич, Є. Петрушевський, М.Ф.К. Хаммуді
}

Національний університет фізичного виховання і спорту України, Київ, Україна

Резюме. Мета. Порівняння стану психофізіологічних функцій та динамічної м'язової витривалості руху кисті (за показниками тепінг-тесту) спортсменок у різних ігрових видах спорту. Методи. Для визначення стану психофізіологічних функцій та динамічної м'язової витривалості руху кисті використовували діагностичний комплекс «Діагност-1» (М. В. Макаренко, В. С. Лизогуб). Відповідно до мети роботи досліджували латентні періоди простої зорово-моторної реакції, простої і складної реакції вибору, ефективність сенсомоторної діяльності, динамічність нервових процесів, точність реакції на рухомий об'єкт, основні властивості нервової системи, динамічну м'язову витривалість руху кисті тощо. Результати. За результатами дослідження, ігрові види спорту сприяють розвитку, вдосконаленню однієї з основних властивостей центральної нервової системи - функціональної рухливості нервових процесів, що цілком узгоджується з відомими літературними даними про вплив фізичних навантажень і занять різними видами спорту на формування і стан цих властивостей. Це певною мірою підтвердив кореляційний аналіз отриманих даних - функціональна рухливість нервових процесів у режимі нав'язаного ритму асоціювалася зі спеціальним спортивним стажем спортсменок $(p<0,05)$, у режимі зворотного зв'язку - з віком обстежених спортсменок ( $p<0,01)$. За рівнем функціональної рухливості нервових процесів обстежені спортсменки (волейболістки і гандболістки) не відрізнялися. Удосконалення спеціальної підготовленості обстежених волейболісток і гандболісток було пов'язано насамперед з розвитком функціональної рухливості нервових процесів та точності реакції на рухомий об'єкт. Більш точними у реакції на рухомий об'єкт за кількістю реакцій випередження і середнім відхиленням у реакціях випередження виявилися обстежені гандболістки (спортсменки з вищим рівнем спортивної майстерності). Більш високий психофізіологічний статус за показниками сили нервових процесів упродовж довготривалих сенсомоторних навантажень (у режимі нав'язаного ритму) продемонстрували волейболістки (спортсменки з більшим стажем спортивного тренування).

Ключові слова: стан психофізіологічних функцій, динамічна м'язова витривалість руху кисті, волейбол, гандбол.

State of psychophysiological functions and dynamic muscular endurance of female athletes in team sports

S. Fedorchuk, O. Shlonska, O. Borysova, I. Kohut, V. Marynych, Ye. Petrushevskyi, M. F. K. Hammoodi

National University of Physical Education and Sport of Ukraine, Kyiv, Ukraine

Abstract. The objective of the study was to compare the state of psychophysiological functions and dynamic muscular endurance of hand movement (according to the indices of the tapping test) of female athletes in different team sports. Methods. The diagnostic complex «Diagnost-1» (M. V. Makarenko, V. S. Lyzogub) was used to determine the state of psychophysiological functions and dynamic muscular endurance of the movement of the athletes' hands. In accordance with the objective of the work, the latent periods of simple visual-motor reaction, simple and complex reaction of choice, efficiency of sensorimotor activity, dynamics of nervous processes, accuracy of reaction to a moving object, basic properties of the nervous system (functional mobility and 
strength of nervous processes), dynamic muscular endurance of hand movement, etc. were studied. Results. According to the findings, team sports contribute to the development and improvement of one of the main properties of the central nervous system - functional mobility of nervous processes, which is consistent with the known literature on the impact of exercise and various sports events on the formation and condition of these properties. This was to some extent confirmed by correlation analysis of the obtained data - functional mobility of nervous processes in the mode of imposed rhythm was associated with special sports experience of athletes $(p<0.05)$, whereas in the feedback mode - with the age of the examined athletes $(p<0.01)$. According to the level of functional mobility of nervous processes, no differences between examined athletes (volleyball players and handball players) were found. Special fitness improvement of the examined athletes was primarily associated with the development of functional mobility of nervous processes and the accuracy of reaction to a moving object. Examined handball players (with a higher level of sports skills) were more accurate in reaction to a moving object in terms of the number of anticipation reactions and the average deviation in anticipation reactions. Volleyball players (athletes with more experience in sports training) showed a higher psychophysiological status in terms of the strength of nervous processes during long-term sensorimotor loads (in the mode of imposed rhythm). Keywords: state of psychophysiological functions, dynamic muscular endurance of hand movement, volleyball, handball.

Постановка проблеми. Волейбол i гандбол - ігрові види спорту, які належать до ситуаційних видів та відзначаються високим рівнем травматизму. Дослідження особливостей формування нейродинамічних фрункцій, індивідуальнотипологічних властивостей основних нервових процесів спортсменок ігрових видів спорту, у взаємозв'язку з успішністю спортивної діяльності, рівнем адаптації до специфічних фрізичних навантажень, має не лише теоретичний інтерес, а й практичне значення [1-3]. Наразі, особливого значення набуває комплексне вивчення загальної та спеціальної підготовленості спортсменок ігрових видів спорту з урахуванням стану психофрізіологічних функцій у передзмагальному періоді для розроблення практичних рекомендацій щодо підвищення ефективності змагальної діяльності.

Встановлено, що результативність змагальної діяльності в ігрових видах спорту у жінок залежить від функціональних можливостей та психофрізіологічного стану спортсменок, а також біологічних особливостей жіночого організму гормональних циклічних змін фрункцій усіх його систем [1, 4]. Результативність в ігрових видах спорту залежить перш за все від швидкісних процесів у нервовій системі спортсменок [5-7]. Разом $з$ тим відомо, що розвиток властивостей основних нервових процесів відповідає характеру фрізичних навантажень [8-11].

Мета дослідження - порівняння стану психофрізіологічних фуннкцій і динамічної м'язової витривалості руху кисті спортсменок у різних ігрових видах спорту (волейбол і гандбол).

Методи дослідження. Для визначення стану психофрізіологічних функцій і динамічної м'язової витривалості руху кисті спортсменок (за показниками тепінг-тесту) використовували діагнос- тичний комплекс «Діагност-1» (М. В. Макаренко, В. С. Лизогуб) [12]. Статистичну обробку даних проводили за допомогою методів непараметричної статистики. Для опису вибіркового розподілу вказували медіани та міжквартильний розкид (Me [25 \%; 75 \%]). Для порівняння незалежних вибірок використовували критерій Манна-Уітні, для кореляційного аналізу - критерій Спірмана.

Результати дослідження та їх обговорення. Дослідження проводили на базі Науково-дослідного інституту НУФВСУ. У ньому як обстежувані брали участь 31 спортсменка (I-II дорослий розряд, кандидати в майстри спорту, майстри спорту) віком 16-21 рік, які займаються ігровими видами спорту (волейбол, гандбол), що належать до ситуаційних видів та характеризуються переважанням динамічної швидкісно-силової роботи, високою емоційністю і травматичністю. Ці види спорту вимагають високої сили і рухливості нервових процесів, стійкості центральної нервової системи (ЦНС) до перешкод в умовах значної нервово-емоційної напруженості, творчих здібностей та особливих вимог до розумової працездатності, пам'яті й уваги [7]. Вважається, що особлива здатність до нестандартних ситуаційних навантажень притаманна спортсменам 3 холеричним і сангвінічним типами темпераменту [7].

Під час проведення комплексних біологічних досліджень за участю спортсменів відповідно до принципів біоетики дотримувалися розробленої в лабораторії теорії і методики спортивної підготовки і резервних можливостей спортсменів НДІ НУФВСУ «Програми комплексного біологічного дослідження особливостей функціональних можливостей спортсменів», а також законодавства України про охорону здоров'я та Гельсінкської декларації 2000 р., директиви Європейського то- 
ТАБЛИЦЯ 1 - Показники стану психофізіологічних функцій спортсменок (n= 31), Ме [25 \%; 75 \%]

\begin{tabular}{|l|c|c|}
\hline \multicolumn{1}{|c|}{ Показники } & $\begin{array}{c}\text { I група, волейбол } \\
\text { (n = 16) }\end{array}$ & $\begin{array}{c}\text { II група, гандбол } \\
\text { (n= 15) }\end{array}$ \\
\hline Латентний період простої зорово-моторної реакції, мс & $270,67[258,06 ; 281,72]$ & $272,50[240,35 ; 285,73]$ \\
\hline Латентний період простої реакції вибору (одного сигналу з трьох), мс & $390,67[368,89 ; 435,56]$ & $391,89[363,56 ; 458,56]$ \\
\hline Латентний період складної реакції вибору (двох сигналів з трьох), мс & $460,44[442,12 ; 496,69]$ & $476,24[433,17 ; 507,32]$ \\
\hline $\begin{array}{l}\text { Сила нервових процесів (тест 5 хв, режим зворотного зв'язку), } \\
\text { загальна кількість оброблених сигналів }\end{array}$ & $575,00[549,50 ; 616,00]$ & $567,00[529,00 ; 614,00]$ \\
\hline Функціональна рухливість нервових процесів (тест 5 хв), с & $70,87[67,33 ; 73,02]$ & $70,59[66,36 ; 74,00]$ \\
\hline Точність реакції на рухомий об'єкт, кількість точних влучень & $11,00[8,50 ; 14,50]$ & $14,00[12,00 ; 15,00]$ \\
\hline Кількість реакцій випередження & $42,00[36,00 ; 46,00]^{*}$ & $37,00[33,00 ; 40,00]$ \\
\hline Кількість реакцій запізнювання & $39,00[32,50 ; 41,50]$ & $39,00[35,00 ; 43,00]$ \\
\hline Середнє відхилення в реакції на рухомий об'єкт, мс & $26,75[22,90 ; 34,45]$ & $23,60[19,60 ; 25,80]$ \\
\hline Середнє відхилення в реакції випередження, мс & $32,35[29,65 ; 40,50]^{*}$ & $26,90[24,40 ; 37,10]$ \\
\hline Середнє відхилення в реакції запізнювання, мс & $28,35[25,70 ; 33,45]$ & $26,10[21,00 ; 31,30]$ \\
\hline Вік, років & $19,00[17,50 ; 19,00]$ & $18,00[18,00 ; 19,00]$ \\
\hline Спеціальний спортивний стаж (волейбол/гандбол), років & $7,00[6,75 ; 9,00]$ & $8,00[6,00 ; 10,00]$ \\
\hline Загальний спортивний стаж, років & $11,00[8,50 ; 13,50]^{*}$ & $8,00[6,00 ; 10,00]$ \\
\hline
\end{tabular}

* $p<0,05$ - значущі різниці між I і II групами за тестом Манна-Уітні

вариства 86/609 щодо участі людей у медикобіологічних дослідженнях [3].

Відповідно до мети роботи у спортсменок досліджували латентні періоди простої зорово-моторної реакції, латентні періоди простої і складної реакції вибору, ефективність сенсомоторної діяльності (визначали за часом мінімальної експозиції сигналів у режимі зворотного зв'язку), динамічність нервових процесів (визначали за часом виходу на мінімальну експозицію в режимі зворотного зв'язку), точність реакції на рухомий об'єкт (РPO), кількість реакцій випередження і запізнювання та середнє відхилення у РРО, основні властивості нервової системи (у тому числі функціональну рухливість нервових процесів - ФРНП і силу нервових процесів СНП). Динамічну м'язову витривалість руху кисті спортсменок визначали за максимальним темпом руху кисті домінантної і субдомінантної рук впродовж 60 с за методикою тепінг-тесту [12]. Спортсменки були розподілені на дві групи: । волейболістки (I-II дорослий розряд, кандидати в майстри спорту) віком 17-21 рік $(n=16)$ і II гандболістки (кандидати в майстри спорту, майстри спорту) віком $16-19$ років $(n=15)$, які не відрізнялися за спеціальним спортивним стажем (відповідно - волейбол/гандбол). Загальний спортивний стаж (у різних видах спорту) в обстежених волейболісток був більшим ( $<<0,05)$ : у I групу потрапили більш досвідчені спортсменки (табл. 1).

За результатами проведених досліджень виділені групи спортсменок за тестом Манна-Уітні значуще не відрізнялися за переважною більшістю вимірюваних психофрізіологічних показників, a саме: за латентними періодами та іншими показниками простої зорово-моторної реакції, простої і складної реакції вибору, за показниками ефективності сенсомоторної діяльності, динамічності нервових процесів, ФРНП і СНП у режимі зворотного зв'язку (див. табл. 1), а також ФРНП у режимі нав'язаного ритму (табл. 2). Час виходу на мінімальну експозицію в режимі зворотного зв'язку, тобто час впрацьовування, з ускладненням умов тестування збільшувався у спортсменок обох груп, але в групі гандболісток ці зміни були менш суттєві, що дозволяє зробити припущення про певною мірою вищу динамічність нервових процесів у зазначеній групі.

Встановлено відмінності між виділеними групами спортсменок за деякими показниками СНП у режимі нав'язаного ритму $(\mathrm{p}<0,05)$. Серед обстежених волейболісток і гандболісток виявлено переважання респонденток з низькою і нижче середньої силою нервових процесів за загальним відсотком помилок при тривалих сенсомоторних навантаженнях (див. табл. 2).

Проте серед волейболісток виявлено превалювання респонденток з більш високими показниками СНП при швидкості пред'явлення і переробки подразників $50 \mathrm{cигн/Хв} \mathrm{та} 90 \mathrm{cигн/хв,}$ що певною мірою свідчить про більш високу сенсомоторну витривалість, вищу працездатність головного мозку у спортсменок ( групи (див. табл. 2) і, можливо, пояснюється більшим загальним спортивним стажем спортсменок цієї групи, хоча кореляційний аналіз отриманих даних виявив зв'язок СНП (як у режимі зворотного зв'язку, так і в режимі нав'язаного ритму) тільки з віком обстежених спортсменок (табл. 3,4$)$. 
ТАБЛИЦЯ 2 - Показники стану психофізіологічних функцій спортсменок (режим нав'язаного ритму) (n = 24), Ме [25 \%; $75 \%$ ]

\begin{tabular}{|l|c|c|}
\hline \multicolumn{1}{|c|}{ Показники } & $\begin{array}{c}\text { I група, волейбол } \\
\text { (n=16) }\end{array}$ & $\begin{array}{c}\text { II група, гандбол } \\
\text { (n= 8) }\end{array}$ \\
\hline Функціональна рухливість нервових процесів (режим нав'язаного ритму), сигн/хв & $90,00[80,00 ; 100,00]$ & $85,00[75,00 ; 100,00]$ \\
\hline Сила нервових процесів (режим нав'язаного ритму), \% помилок & $21,21[19,34 ; 24,62]$ & $22,15[17,21 ; 28,96]$ \\
\hline $\begin{array}{l}\text { Кількість помилок (режим нав'язаного ритму), швидість пред'явлення і переробки } \\
\text { подразників 50 сигн/хв }\end{array}$ & $0,00[0,00 ; 0,00]^{*}$ & $1,00[0,00 ; 1,00]$ \\
\hline $\begin{array}{l}\text { Кількість помилок (режим нав'язаного ритму), швидкість пред'явлення і переробки } \\
\text { подразників 90 сигн/хв }\end{array}$ & $2,50[1,50 ; 4,00]^{*}$ & $5,50[3,00 ; 7,00]$ \\
\hline Вік, років & $19,00[17,50 ; 19,00]$ & $18,00[17,00 ; 19,00]$ \\
\hline Спеціальний спортивний стаж (волейбол/гандбол), років & $7,00[6,75 ; 9,00]$ & $8,00[6,00 ; 8,00]$ \\
\hline Загальний спортивний стаж, років & $11,00[8,50 ; 13,50]^{* *}$ & $8,00[6,00 ; 8,00]$ \\
\hline
\end{tabular}

${ }^{*} p<0,05,{ }^{* *} p<0,01-$ значущі різниці між I i II групами за тестом Манна-Уітні

ТАБЛИЦЯ 3 - Основні кореляційні зв'язки (за Спірменом) психофізіологічних показників (режим зворотного зв'язку) 3 віком і спортивним стажем $(n=31), r_{s}$

\begin{tabular}{|l|c|c|}
\hline \multicolumn{1}{|c|}{ Показники } & \multicolumn{2}{c|}{ Кореляційні зв'язки, $\mathrm{r}_{\mathrm{s}}$} \\
\cline { 2 - 3 } & \multicolumn{2}{c|}{$\begin{array}{c}\text { 3і спеціальним } \\
\text { спортивним стажем }\end{array}$} \\
\hline Сиком & $0,49^{* *}$ & - \\
\hline Сила нервових процесів (тест 5 хв), кількість оброблених сигналів в інтервалі 30-60 с & $0,43^{*}$ & - \\
\hline Сила нервових процесів (тест 5 хв), кількість оброблених сигналів в інтервалі 130-150 с & $0,37^{*}$ & - \\
\hline Сила нервових процесів (тест 5 хв), кількість оброблених сигналів в інтервалі 180-210 с & $0,43^{*}$ & - \\
\hline Сила нервових процесів (тест 5 хв), кількість оброблених сигналів в інтервалі 210-240 с & $0,49^{* *}$ & - \\
\hline Функціональна рухливість нервових процесів (тест 5 хв), с & $-0,46^{* *}$ & - \\
\hline
\end{tabular}

${ }^{*} p<0,05,{ }^{* *} p<0,01$

Для досягнення високих результатів в ігрових видах спорту велику роль відіграє ФРНП [5-7]. Це певною мірою підтвердив кореляційний аналіз отриманих даних (див. табл. 4) - саме ФРНП за відповідним показником у режимі нав'язаного ритму асоціювалася зі спеціальним спортивним стажем спортсменок $(p<0,05)$. Проте в режимі зворотного зв'язку ФРНП за відповідним показником (див. табл. 3) була пов'язана тільки з віком обстежених спортсменок ( $<<0,01)$. Відомо, що для ФРНП коефіцієнт Хольцингера (показник генетичної обумовленості) дорівнює 0,61-0,86 [5]. Відсутність відмінностей за показниками ФРНП між виділеними групами спортсменок дає змо- гу припустити, що саме ця властивість ЦНС була тією основною професійно важливою якістю, за якою спортсменок було відібрано в обидві групи. За отриманими результатами, переважна більшість спортсменок в обох групах характеризувалася середньою ФРНП як за показниками в режимі зворотного зв'язку, так і в режимі нав'язаного ритму. Зазвичай ФРНП та СНП у спортсменів досягають свого максимального розвитку в 20-25 років [5], що дає підстави сподіватися на подальший розвиток цих властивостей в обстежених спортсменок. Слід зазначити, що латентні періоди складної реакції вибору можуть розглядатися як додаткові показники СНП

ТАБЛИЦЯ 4 - Основні кореляційні зв'язки (за Спірменом) психофізіологічних показників (режим нав'язаного ритму) 3 віком і спортивним стажем $(n=24), r_{s}$

\begin{tabular}{|l|c|c|}
\hline \multicolumn{1}{|c|}{ Показники } & \multicolumn{2}{|c|}{ Кореляційні зв'язки, $\mathrm{r}_{\mathrm{s}}$} \\
\cline { 2 - 3 } & з віком & $\begin{array}{c}\text { зі спеціальним } \\
\text { спортивним стажем }\end{array}$ \\
\hline Функціональна рухливість нервових процесів (режим нав'язаного ритму), сигн/хв & - & $0,43^{*}$ \\
\hline $\begin{array}{l}\text { Кількість помилок (режим нав'язаного ритму), швидкість пред'явлення і переробки подразників } \\
90 \text { сигн/хв }\end{array}$ & $-0,44^{*}$ & - \\
\hline $\begin{array}{l}\text { Кількість помилок (режим нав'язаного ритму), швидкість пред'явлення і переробки подразників } \\
110 \text { сигн/хв }\end{array}$ & $-0,41^{*}$ & - \\
\hline
\end{tabular}

${ }^{*} p<0,05$ 
ТАБЛИЦЯ 5 - Показники динамічної м'язової витривалості (тепінг-тест) спортсменок (n = 24), Ме [25 \%; 75 \%]

\begin{tabular}{|l|c|c|}
\hline \multicolumn{1}{|c|}{ Показники } & I група, волейбол (n = 16) & II група, гандбол (n = 8) \\
\hline $\begin{array}{l}\text { Динамічна м'язова витривалість руху кисті домінантної руки (тепінг-тест), кіль- } \\
\text { кість натискань }\end{array}$ & $387,00[365,00 ; 401,00]$ & 370,50 [357,50; 378,50] \\
\hline $\begin{array}{l}\text { Динамічна м'язова витривалість руху кисті субдомінантної руки (тепінг-тест), } \\
\text { кількість натискань }\end{array}$ & $329,00[317,50 ; 357,00]$ & $316,50[310,50 ; 328,50]$ \\
\hline Асиметрія (тепінг-тест) & $16,50[13,00 ; 23,50]$ & $17,50[13,50 ; 20,50]$ \\
\hline
\end{tabular}

і ФРНП [12]. Несуттєві відмінності між групами спортсменок у даному випадку не набули рівня значущості (див. табл. 1).

Дещо подібна ситуація склалася з більшістю показників точності PPO: спортсменки за вимірюваними показниками майже не відрізнялися (див. табл. 1). Проте кількість реакцій випередження і середнє відхилення в реакціях випередження були більшими в групі волейболісток ( $<<0,05)$. Тобто більш точними в PPO за кількістю реакцій випередження і середнім відхиленням у реакціях випередження виявилися обстежені гандболістки, що можна пояснити вищою майстерністю спортсменок цієї групи (в команду гандболісток увійшли переважно майстри спорту та кандидати в майстри спорту).

Одним із показників функціонального стану організму, який характеризує здатність усіх ланок рухового аналізатора до швидкості та витривалості, як зазначав М. В. Макаренко [12], є максимальний темп руху кисті за методикою тепінг-тесту, який визначає динамічну м'язову витривалість. Методика тепінг-тесту досить відома і широко застосовується у сучасній психофрізіології $[2,12$, 13]. Виявлено тенденцію до більшої динамічної м'язової витривалості руху кисті домінантної та субдомінантної рук у спортсменок-волейболісток, але ці відмінності за тестом Манна-Уітні не досягли рівня значущості. Асиметрія за показниками тепінг-тесту між правою та лівою руками в обстежених спортсменок не відрізнялася (табл. 5).

Таким чином, удосконалення спеціальної підготовленості обстежених спортсменок було пов'язане насамперед з розвитком функціональної рухливості нервових процесів та точності реакції на рухомий об'єкт. 3 віком були пов'язані

\section{Література}

1. Игнатьева ВЯ. Гандбол: учебник [Handball: tutorial]. Москва, 2008. 384 с.

2. Ильин ЕП. Дифференциальная психофизиология [Differential psychophysiology]. Санкт-Петербург: Питер, 2001. 464 с.

3. Шинкарук ОА, Лисенко ОМ, Гуніна ЛМ, Карленко ВП, Земцова II, Олішевський СВ та ін. Медико-біологічне забезпечення підготовки спортсменів збірних команд України з олімпійських видів спорту [Medicobiological support of training of athletes of national teams of Ukraine on Olympic sports]. За заг. ред. О. А. Шинкарук. Київ, 2009. 144 с. показники СНП та ФРНП (див. табл. 3, 4), що підтверджує результати інших дослідників. Як було зазначено вище, основні властивості нервової системи генетично обумовлені, але розвиваються й удосконалюються як в онтогенезі [2, 5, $14,15]$, так і в процесі спортивної діяльності [8, $11,16,17]$. Тобто за результатами дослідження ігрові види спорту сприяють розвитку, вдосконаленню однієї з основних властивостей ЦНС, зокрема ФРНП, що цілком узгоджується з відомими літературними даними про вплив фрізичних навантажень і занять різними видами спорту на орормування і стан цих властивостей $[5,9,10,13]$.

\section{Висновки}

1. Удосконалення спеціальної підготовленості обстежених спортсменок було пов'язане насамперед 3 розвитком фрункціональної рухливості нервових процесів та точності реакції на рухомий об'єкт.

2. Виявлено кореляційний зв'язок функціональної рухливості нервових процесів (у режимі нав'язаного ритму) зі спеціальним спортивним стажем спортсменок. За рівнем функціональної рухливості нервових процесів обстежені спортсменки не відрізнялися.

3. Більш точними в реакції на рухомий об'єкт за кількістю реакцій випередження і середнім відхиленням у реакціях випередження виявилися обстежені гандболістки (спортсменки з вищим рівнем спортивної майстерності).

4. Більш високий психофрізіологічний статус за показниками сили нервових процесів упродовж довготривалих сенсомоторних навантажень (у режимі нав'язаного ритму) продемонстрували волейболістки (спортсменки з більшим стажем спортивного тренування).

4. Шахлина ЛГ. Медико-биологические основы спортивной тренировки женщин [Medical and biological foundations of sports training for women] Киев, 2001. 326 c

5. Макаренко МВ, Лизогуб ВС. Онтогенез психофізіологічних функцій людини [Ontogenesis of psychophysiological functions of a person]. Черкаси, 2011. $256 \mathrm{c}$.

6. Лизогуб ВС, Харченко ДМ, Хоменко СМ, Юхименко ЛІ, Петренко ЮО, Явник ОЕ. Онтогенез нейродинамічних фуннцій людини 
[Ontogenesis of human neurodynamic functions]. Фізіологічний журнал. 2002;48(2):123-4.

7. Солодков АС, Сологуб ЕБ. Физиология человека. Общая. Спортивная. Возрастная: учебник [Human physiology. General. Sports. Age Range: Textbook]. M., 2001. $620 \mathrm{C}$.

8. Макаренко Н, Лизогуб В, Безкопыльный А. Формирование свойств нейродинамических функций у спортсменов [Formation of the properties of neurodynamic functions in athletes]. Наука в олимпийском спорте. 2005;2:80-5

9. Лысенко ЕН, Шинкарук ОА. Влияние на проявление нейродинамических свойств спортсменов полового диморфизма и напряженной физической работы [Influence on the manifestation of neurodynamic properties of athletes of sexual dimorphism and strenuous physical work]. Наука и спорт: современные тенденции. 2015;6(1):11-8.

10. Коробейников ГВ. Психофизиология деятельности человека: монография [Psychophysiology of human activity: monograph]. Saarbrucken: «LAP Lambert Academic Publishing», 2011. $126 \mathrm{c}$

11. Fedorchuk S, Lysenko O, Romanyuk V. Neurodynamic properties and psychological characteristics of high qualification sportships with different sports trainings. Bulletin of Tara s Shevchenko National University of Kyiv, Problems of Physiological Functions Regulation. 2018;24(1):27-31. DOI: http:/l dx.doi.org/10.17721/2616_6410.2018.24.27-31

lanasvet778899@gmail.com

shlensk_o@ukr.net

Kuwaitgroupua@gmail.com
12. Макаренко МВ, Лизогуб ВС, Безкопильний ОП. Методичні вказівки до практикуму з диференціальної психофізіології та фізіології вищої нервової діяльності людини [Methodical instructions to the practical works on differential psychophysiology and physiology of higher human nervous activity] Київ-Черкаси, 2014. 102 с.

13. Ильин ЕП. Психомоторная организация человека [Psychomotor organization of a person]. Санкт-Петербург: Питер, 2003. 384 с.

14. Куценко ТВ. Стан психофрізіологічних функцій у дітей молодшого шкільного віку [The state of psychophysiological functions in children of primary school age]. Автореф. дис ... канд. біол. наук: 03.00.13. Київ, 2000. $18 \mathrm{c}$.

15. Макарчук МЮ, Куценко ТВ, Кравченко ВІ, Данилов СА. Психофізіологія: навчальний посібник [Psychophysiology: a textbook]. Київ, 2011 329 c.

16. Shynkaruk O, Lysenko O, Fedorchuk S. Assessment of psychophysiological characteristics of the representatives of cyclic sports. European Psychiatry, Elsevier. 2019;56:679-80.

17. Fedorchuk S, Petrushevskyi Ye. The state of psychophysiological functions in handball players with different experience of sports training. Bulletin of Taras Shevchenko National University of Kyiv, Biology. 2020:81(2):42-5. DOI: http://dx.doi.org/10.17721/1728_2748.2020.81.42-45 